\title{
Mangrove lagoons of the Great Barrier Reef support coral populations persisting under extreme environmental conditions
}

\author{
Emma F. Camp ${ }^{1, *}$, John Edmondson ${ }^{2}$, Annabelle Doheny ${ }^{1,2}$, John Rumney ${ }^{3}$ \\ Amanda J. Grima ${ }^{1}$, Alfredo Huete ${ }^{1}$, David J. Suggett ${ }^{1}$
}

${ }^{1}$ University of Technology Sydney, Climate Change Cluster, Ultimo NSW 2007, Australia

${ }^{2}$ Wavelength Reef Cruises, Port Douglas, QLD 4877, Australia

${ }^{3}$ Great Barrier Reef Legacy, Port Douglas, QLD 4877, Australia

\begin{abstract}
Global degradation of coral reefs has increased the urgency of identifying stress-tolerant coral populations, to enhance understanding of the biology driving stress tolerance, as well as identifying stocks of stress-hardened populations to aid reef rehabilitation. Surprisingly, scientists are continually discovering that naturally extreme environments house established coral populations adapted to grow within extreme abiotic conditions comparable to seawater conditions predicted over the coming century. Such environments include inshore mangrove lagoons that carry previously unrecognised ecosystem service value for corals, spanning from refuge to stress preconditioning. However, the existence of such hot-spots of resilience on the Great Barrier Reef (GBR) remains entirely unknown. Here we describe, for the first time, 2 extreme GBR mangrove lagoons (Woody Isles and Howick Island), exposing taxonomically diverse coral communities (34 species, 7 growth morphologies) to regular extreme low $\mathrm{pH}(<7.6)$, low oxygen $\left(<1 \mathrm{mg} \mathrm{l}^{-1}\right)$ and highly variable temperature range $\left(>7^{\circ} \mathrm{C}\right)$ conditions. Coral cover was typically low $(<5 \%)$, but highly patchy and included established colonies ( $>0.5 \mathrm{~m}$ diameter), with net photosynthesis and calcification rates of 2 dominant coral species (Acropora millepora, Porites lutea) reduced $(20-30 \%)$, and respiration enhanced (11-35\%), in the mangrove lagoon relative to adjacent reefs. Further analysis revealed that physiological plasticity (photosynthetic 'strategy') and flexibility of Symbiodiniaceae taxa associations appear crucial in supporting coral capacity to thrive from reef to lagoon. Prevalence of corals within these extreme conditions on the GBR (and elsewhere) increasingly challenge our understanding of coral resilience to stressors, and highlight the need to study unfavourable coral environments to better resolve mechanisms of stress tolerance.
\end{abstract}

*Corresponding author: emma.camp@uts.edu.au

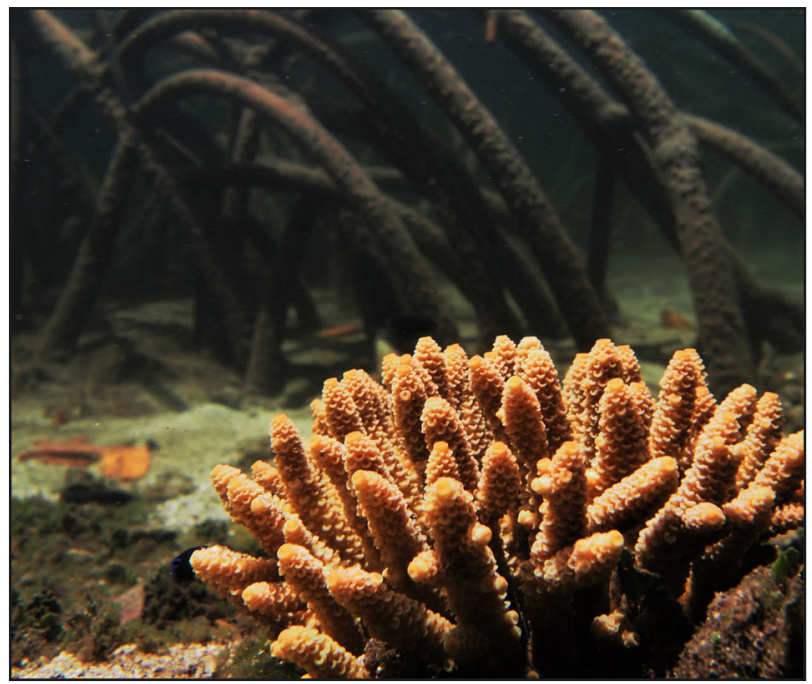

Acropora millepora colony thriving under extreme low $\mathrm{pH}$, low oxygen and highly variable temperatures of a Great Barrier Reef mangrove lagoon.

Photo: Emma Camp

KEY WORDS: Coral reefs · Extreme environments · Mangroves - Climate change $\cdot$ Marginal environments · Symbiodiniaceae $\cdot$ Warming $\cdot$ Ocean acidification

\section{INTRODUCTION}

Progressive decline of coral cover throughout the Great Barrier Reef (GBR) since at least the 1980s (Sweatman et al. 2011, De'ath et al. 2012) has now been superseded by catastrophic coral mortality in just $2 \mathrm{yr}$, from the worst-ever recorded mass coral bleaching $(>30 \%, 2016-2017$; Hughes et al. 2017, 2018). These bleaching events have already led to

(C) The authors 2019. Open Access under Creative Commons by Attribution Licence. Use, distribution and reproduction are unrestricted. Authors and original publication must be credited. 
declines in coral reproductive capacity (Hughes et al. 2019) and reef accretion (McMahon et al. 2019), compromising the potential resilience of the reef to the anticipated increase in frequency and intensity of bleaching events (Oliver et al. 2018). While environmental filtering of thermally tolerant corals surviving after bleaching events will naturally select for some thermally resilient taxa, reductions in coral species that have traits supporting key ecological functions, e.g. reductions in species contributing to habitat provision and rapid reef accretion (Hughes et al. 2018), creates a need to identify and study potential hotspots of coral resilience where these species will be supported. Such hot-spots of resilience include both coral refugia (locations maintaining favourable conditions being lost elsewhere, sensu Keppel \& WardellJohnson 2012; e.g. the northern Red Sea, Osman et al. 2018) and habitats housing intrinsically resilient coral populations (reviewed by Camp et al. 2018a).

To date, studies of coral refugia environments documented on the GBR have focussed on environments that dampen the effects of heat stress; for example, microrefugia operating over small scales appeared to enable stress-sensitive Acropora coral populations to persist through the 2016-2017 marine heatwaves (Hoogenboom et al. 2017). Bleaching models have also predicted that the southern end of the GBR may act as a temporary coral refugium (van Hooidonk et al. 2013). However, with current rates of ocean warming (IPCC 2014), and the increased frequency of marine heatwaves (Oliver et al. 2018), it remains unclear how long this geographic thermal refuge may operate. Deep reefs of the GBR were also documented to provide transient refuge to corals during the 2016-2017 bleaching event (Frade et al. 2018). Although incidence of coral bleaching was lower at deep reef sites $(40 \mathrm{~m})$, the cold water associated with the refugia resulted from seasonal oceanographic processes, temporally constraining the refuge capacity (Frade et al. 2018). These findings are consistent with other global upwelling refugia sites, where such temporal refuge restrictions operate (e.g. Chollett et al. 2010). In contrast, more temporally stable refugia on the GBR are inshore, turbid reefs. Inshore reefs of the GBR attenuate solar irradiance that otherwise can exacerbate thermal stress, resulting in reduced bleaching severity and sustained coral cover post-bleaching (Morgan et al. 2017). While refugia will contribute to aiding some coral populations through periods of stress, their temporal and spatial restrictions, combined with the fact that most refugia only offset a single stressor (reviewed by Camp et al. 2018b), means that there is arguably a more time-critical need to identify and study naturally resilient coral populations in order to (1) understand which coral species can best survive multiple stressors, (2) identify the key mechanisms that support coral survival and (3) reveal any associated biological and ecological costs to corals with enhanced stress tolerance. Such knowledge can aid decisions that currently need to be made regarding which species should be targeted for restoration and adaptive management options (e.g. the GBR; Suggett et al. 2019), while highlighting potential risks associated with biodiversity and reef services.

Studies from natural extreme reef environments, such as carbon dioxide vents (e.g. Fabricius et al. 2011, Enochs et al. 2015), back reef tide pools on Ofu Island (Smith et al. 2007, Oliver \& Palumbi 2009, 2011a) and mangrove lagoons (Camp et al. 2016a, 2017) have revealed that phenotypic plasticity, particularly in traits related to energy acquisition, are important in supporting coral survival (Camp et al. 2018b). For example, under naturally acidified waters, corals continue to calcify through increased photosynthesis rates to meet the required energy demands (Strahl et al. 2015). Changes in dominant algal symbiont (e.g. Oliver \& Palumbi 2011b) and increased photosynthetic efficiency per cell of Symbiodiniaceae (Camp et al. 2016b) have also been shown to facilitate coral survival in naturally variable in-shore reef habitats. In mangrove lagoons, corals also appear to enhance respiration rates, indicative of increased heterotrophy, which may offset losses to photosynthetic capacity and therefore facilitate their survival (Camp et al. 2017). Mangrove lagoons are of particular interest because they consistently expose resident coral populations to low $\mathrm{pH}$, low oxygen and warmer waters relative to adjacent reefs (Seychelles, Indonesia, Camp et al. 2016a; New Caledonia, Camp et al. 2017), i.e. the primary trio of stressors predicted to impact coral reefs under climate change (IPCC 2014, Camp et al. 2018b). For example, in New Caledonia, corals in the Bouraké mangrove lagoon were regularly exposed to $\mathrm{pH}$ below 7.4, oxygen below $2 \mathrm{mg} \mathrm{l}^{-1}$, and temperature $2^{\circ} \mathrm{C}$ higher than the adjacent reef (Camp et al. 2017). Whether mangrove lagoons of the GBR have similarly extreme abiotic conditions and house abundant and/or diverse coral communities remains entirely unknown. Furthermore, if these locations exist, whether resident coral populations employ plasticity in energy acquisition modes and conform with observations reported from other extreme inshore coral habitats is also unknown.

Here we surveyed $250 \mathrm{~km}$ of the northern GBR, visiting lagoons located on 5 off-shore islands. From this exploration, we identified for the first time 2 man- 
grove lagoons with relatively extreme environmental conditions (low $\mathrm{pH}$, low oxygen and highly varying temperature), coupled to significant coral cover and/or diversity. Targeted studies of resident corals at one of these locations (Woody Isles) were then used to test our hypotheses that the mangrove corals relative to adjacent reef corals would (1) have enhanced respiration rates relative to net photosynthesis, (2) house different dominant Symbiodiniaceae taxa, and consequently (3) use different photosynthetic 'strategies' to survive the extreme physicochemical conditions. Through this work, we demonstrate that physiological plasticity (photosynthetic 'strategy') combined with unique symbiont diversity supports coral survival in the GBR mangrove lagoons, but that reductions in calcification rates are an associated survival trade-off. These findings contribute to the growing body of evidence that these traits are important for coral survival under suboptimal environmental conditions that are analogous to those predicted under climate change (Camp et al. 2018b).

\section{MATERIALS AND METHODS}

Five islands (Woody Isles, Two Isles, Hope Isles, Nymph Isles and Howick Island) adjacent to coral reefs on the GBR were investigated in June 2017 for prevalence of coral communities and associated abiotic conditions (Table 1). These sites were selected based on local knowledge (J. Rumney pers. obs.) and prior knowledge of mangrove lagoon geomorphologies likely to house extreme coral communities (Camp et al. 2016a, 2017). Sites were initially examined via satellite imagery (Google Earth ${ }^{\mathrm{TM}}$ ) for key features (e.g. distance from a coral reef, presence of channels in the mangroves, their orientation to wind direction and image optical signatures characteristic of corals). Upon exploration, we found that 2 of these sites, Woody Isles $\left(16.388^{\circ} \mathrm{S}, 145.566^{\circ} \mathrm{E}\right)$ and Howick Island $\left(14.497^{\circ} \mathrm{S}, 144.972^{\circ} \mathrm{E}\right)$, housed corals living within the mangrove lagoons (Fig. S1 in the Supplement at www.int-res.com/articles/suppl/m625p001_ supp.pdf). Both sites had no visible significant freshwater catchment inputs and were semi-enclosed lagoons surrounded by mangrove forests. Coral community composition (cover, diversity and sizefrequency distribution) and physicochemical conditions were determined, with additional seasonal abiotic sampling and assessment of coral physiology subsequently conducted at Woody Isles due to ease of boat access (February-April 2018, Table 1).

\subsection{Environmental characterisation}

Continuous sensor-based measurements (total $\mathrm{pH}$ $\left[\mathrm{pH}_{\mathrm{T}}\right]$, salinity, temperature $\left[{ }^{\circ} \mathrm{C}\right]$ and oxygen $\left.\left[\mathrm{mg} \mathrm{l}^{-1}\right]\right)$ with SeapHOx ${ }^{\mathrm{TM}}$, combined with periodic spot-sampling (via discrete water samples analysed with a $\mathrm{pH}$

Table 1. Summary of all research activities undertaken, including the date, site and habitat

\begin{tabular}{|c|c|c|c|}
\hline Activity & Date & Site(s) & Habitat \\
\hline Initial site exploration & June 2017 & $\begin{array}{l}\text { Woody Isles } \\
\text { Howick Island } \\
\text { Two Isles } \\
\text { Hope Isles } \\
\text { Nymph Isles }\end{array}$ & Mangrove lagoon \\
\hline Benthic characterisation & June 2017 & $\begin{array}{l}\text { Woody Isles } \\
\text { Howick Island }\end{array}$ & Mangrove lagoon \& reef \\
\hline $\begin{array}{l}\text { High resolution }(1 \mathrm{~min}) \text { SeapHOx }{ }^{\mathrm{TM}} \text { data collected at the } \\
\text { mangrove lagoon over } 48 \mathrm{~h} \text { coupled with discrete water } \\
\text { sample analysis from adjacent reef habitat }(\mathrm{n}=12)\end{array}$ & June 2017 & $\begin{array}{l}\text { Woody Isles } \\
\text { Howick Island }\end{array}$ & Mangrove lagoon \& reef \\
\hline $\begin{array}{l}\text { Seasonal ( } 2 \mathrm{~d} \text { in winter, } \mathrm{n}=10 \text {; and } 3 \mathrm{~d} \text { in summer, } \mathrm{n}=15 \text { ) } \\
\text { seawater carbonate chemistry analysis }\end{array}$ & $\begin{array}{l}\text { June } 2017 \& \\
\text { February } 2018\end{array}$ & Woody Isles & Mangrove lagoon \\
\hline Long-term (50 d) SeapHOx ${ }^{\mathrm{TM}}$ data & February-April 2018 & Woody Isles & Mangrove lagoon \\
\hline $\begin{array}{l}\text { Rates of light and dark calcification, respiration and } \\
\text { photosynthesis for Acropora millepora and Porites lutea } \\
\text { ( } \mathrm{n}=4 \text { per species and habitat) }\end{array}$ & April 2018 & Woody Isles & Mangrove lagoon \& reef \\
\hline $\begin{array}{l}\text { Fragment collection of } A \text {. millepora and } P \text {. lutea }(\mathrm{n}=4 \text { per } \\
\text { species and habitat) for Symbiodiniaceae assessments }\end{array}$ & April 2018 & Woody Isles & Mangrove lagoon \& reef \\
\hline
\end{tabular}


meter [913, Metrohm] and multi-meter [3430, WTW] for temperature, salinity and oxygen) were used to characterise the physicochemical conditions at Woody Isles and Howick Island (see Table 1 for summary). Prior to sampling, all sensors were inter-calibrated for comparison consistency. Our initial site exploration in June 2017 only allowed for short (48 h) high-resolution (1 min sampling interval) data to be collected at the Woody Isles and Howick Island mangrove lagoons that were coupled with spot-sampling at the adjacent reef habitats (Table 1, Table S1). We used $t$-tests to compare data between habitats, with the SeapHOx ${ }^{\mathrm{TM}}$ data matching the time of spot-sampling used for the analysis.

At the Woody Isles mangrove lagoon, additional long-term deployment of the SeapHOx ${ }^{\mathrm{TM}}$ between February and April 2018 generated a 50 d (10 min resolution) dataset. The SeapHOx ${ }^{\mathrm{TM}}$ was deployed at ca. $1 \mathrm{~m}$ (at lowest tidal point), and discrete water samples were collected on initial deployment of the SeapHOx ${ }^{\mathrm{TM}}$ to corroborate the sensor readings (as per Camp et al. 2017). Linear regressions were conducted in SigmaPlot to assess how temperature, salinity and oxygen were influenced by tidal height and time of day (as per Camp et al. 2017). High tide and low tide data obtained from the Australian Bureau of Meteorology were matched to the corresponding SeapHOx ${ }^{\mathrm{TM}}$ data for that time to assess the effect of tidal height. Light (Lux) was measured through the deployment of $\mathrm{HOBO}^{\circledR}$ Pendant light loggers (Microdaq) and converted to photosynthetically active radiation (PAR, ca. 3\% accuracy; see Long et al. 2012). Linear regressions were conducted from sunrise to daytime maximum (when light intensity is increasing, ca. 06:00-14:00 h) and then from daytime maximum through to the night-time (when light intensity is decreasing, ca. 14:10-05:50 h).

A seasonal comparison of the seawater carbonate chemistry was also undertaken at Woody Isles through the collection of discrete water samples (June 2017 and February 2018). Initial samples were collected at 07:00 $\mathrm{h}$ and repeated every $3 \mathrm{~h}$ until 19:00 $\mathrm{h}(2 \mathrm{~d}$ in winter, $\mathrm{n}=10$; and $3 \mathrm{~d}$ in summer, $\mathrm{n}=15$, Table 1 ). Seawater samples $(500 \mathrm{ml})$ were stored in borosilicate bottles and fixed with $\mathrm{HgCl}_{2}$ and sealed for later measurements of total alkalinity $\left(A_{T}\right)$. Samples were transported back to the University of Technology Sydney where they were processed for $\mathrm{A}_{\mathrm{T}}$ using an autotitrator (916 TiTouch, Metrohm), verified with certified reference materials distributed by A. Dickson (Batch 137, Scripps Institute of Oceanography). Values of $A_{T}$ were used with corresponding in situ $\mathrm{pH}_{\mathrm{T}}$, temperature, salinity and depth $(\mathrm{m})$ to determine the remaining carbonate system parameters, using CO2SYS, with the dissociation constants of Lueker et al. (2000) for K1 and K2, Dickson (1990) for $\mathrm{KHSO}_{4}$ and Uppström (1974) for boric acid. Salinity $(\mathrm{S}=36$ ) dissolved inorganic carbon $\left(\mathrm{nC}_{\mathrm{T}}\right)$ to total alkalinity $\left(\mathrm{nA}_{\mathrm{T}}\right)$ plots were generated to assess the dominant mechanisms influencing the carbonate chemistry, whereby a location where calcification and dissolution are dominant processes has a linear regression slope approaching 2 (Suzuki \& Kawahata 2003, Kleypas et al. 2011).

\subsection{Benthic characterisation}

To assess the coral cover and size-frequency distribution, continuous line intercept transects were undertaken in June 2017 (as per Gardner et al. 2019). At each location, 3 transects $(30 \mathrm{~m}$ each) were randomly located and data recorded using a high definition camera (GoPro Hero5). Data were later analysed to the highest possible taxonomic resolution. Due to the heterogeneous nature of the mangrove lagoons, a coral species list was generated from all reported coral species observed during the sampling period.

\subsection{Woody Isles coral physiology}

Rates of light and dark calcification, respiration and photosynthesis were determined (April 2018) for 2 dominant coral species (Acropora millepora and Porites lutea) found within the Woody Isles mangroves and adjacent reef habitats $(\mathrm{n}=4$ per species per habitat, Table 1). Symbiodiniaceae associated with each coral species across habitats were also identified and quantified. Fragments $(<5 \mathrm{~cm})$ were collected from their native habitat and transported to the operations vessel ('Wavelength 5 '), where they were incubated for $2 \mathrm{~h}$ in the light and then $2 \mathrm{~h}$ in the dark. Incubations were conducted in $250 \mathrm{ml}$ glass chambers filled with native seawater that were continuously mixed via a magnetic stir plate. Prior to incubation, any non-live coral tissue (e.g. coral skeleton, attached rock/substrate) was covered with parafilm to prevent biological alteration of incubated seawater. Temperature was controlled via a water bath, and maintained within $0.2^{\circ} \mathrm{C}$ of the in situ ambient temperatures in the native environment (reef: $28.2^{\circ} \mathrm{C}$, mangrove: $28.1^{\circ} \mathrm{C}$ ). To determine an appropriate light intensity for incubation, we used the light saturation coefficient $\left(E_{\mathrm{k}}\right)$, which provides a measure of the long-term light history to which corals are acclimated (e.g. Suggett et al. 2012). Values of $E_{\mathrm{k}}$ were 
determined using a pulse amplitude-modulated fluorometer (Diving PAM, Walz) and rapid light curves (RLCs) as detailed below, and were ca. 220 umol photons $\mathrm{m}^{-2} \mathrm{~s}^{-1}$ across all corals. Light intensity for the incubations was delivered via white-LED aquarium lights (Hydra, AI). Dark conditions were created by covering the chambers with black-out material.

Rates of light and dark calcification were determined by the alkalinity anomaly technique (Smith \& Kinsey 1978) corrected for any changes in $A_{T}$ of 3 seawater controls, during the light and dark incubations, respectively (as previously described by Camp et al. 2017). Net photosynthesis $\left(\mathrm{P}_{\mathrm{N}}\right)$ and respiration (R) were determined by changes in oxygen during the light and dark incubations, respectively, corrected for changes in oxygen of the controls. Gross photosynthesis $\left(G_{P}\right)$ was determined by the addition of $P_{N}$ and $R$. All rates were normalised to the incubation volume, time and coral surface area, which was determined from 3D scans of the corals (Blue Light Geomagic capture) and the model software Geomagic Wrap. Additional fragments were taken from each coral species per habitat $(\mathrm{n}=4)$ to determine the Symbiodiniaceae cell density. Tissue was removed from each nubbin with an air-pick, and an aliquot of the slurry was used to quantify cell counts using microscopy and normalised for surface area (Camp et al. 2016b). Two-way ANOVAs with post hoc Tukey HSD were conducted in R Studio version 1.1.423 (RStudio Team 2015) to compare habitat and species differences in physiological parameters. Tests of normality (Q-Q plots) and homogeneity of variance (Levene's test) were passed.

A diving PAM fluorometer with fibre optic was programmed (Measurement intensity [MI]: 12; Gain: 12; Saturating intensity [SI]: 12; Saturation width [SW]: $0.8 \mathrm{~s}$; Light curve interval [LC-INT]: 3 ) to deliver RLCs to assess for differences in photobiological traits of the coral-associated Symbiodiniaceae within each habitat (Suggett et al. 2012, Nitschke et al. 2018). For each RLC, acquisitions were applied with 8 actinic light steps and an initial dark measurement, whereby each light intensity was applied for $20 \mathrm{~s}$. The actinic light levels (calibrated against a factory-calibrated LI-192 quantum sensor, Li-Cor) of the RLC were 0, $186,214,360,456,670,1070,1547$ and $1975 \mu \mathrm{mol}$ photons $\mathrm{m}^{-2} \mathrm{~s}^{-1}$. Minimum $\left(F_{\mathrm{o}}, F_{\mathrm{o}}{ }^{\prime}, F^{\prime}\right)$ and maximum $\left(F_{\mathrm{m}}, F_{\mathrm{m}}{ }^{\prime}\right)$ fluorescence yields were obtained (where the prime notation denotes measurements performed in the light-acclimated state) and then used to calculate [1-C] and [1-Q] as per Suggett et al. (2015):

$$
\begin{gathered}
{[1-\mathrm{C}]=\left[\left(F_{\mathrm{m}}{ }^{\prime}-F^{\prime}\right) /\left(F_{\mathrm{m}}{ }^{\prime}-F_{\mathrm{o}}{ }^{\prime}\right)\right]} \\
{[1-\mathrm{Q}]=\left[\left(F_{\mathrm{m}}{ }^{\prime}-F_{\mathrm{o}}{ }^{\prime}\right) / F_{\mathrm{m}}{ }^{\prime}\right] /\left[\left(F_{\mathrm{m}}-F_{\mathrm{o}}\right) / F_{\mathrm{m}}\right]}
\end{gathered}
$$

Comparisons between [1-C] photochemical quenching (the fraction of open PSII reaction centres) versus [1-Q] dynamic nonphotochemical quenching was undertaken to assess differences in the photochemical quenching patterns of coral-associated Symbiodiniaceae within each habitat (Suggett et al. 2015, Nitschke et al. 2018).

\subsection{Symbiodiniaceae diversity}

Small fragments $(1 \mathrm{~cm})$ for each of $A$. millepora and $P$. lutea $(\mathrm{n}=4)$ were removed from independent colonies and immediately preserved in RNAlater (Ambion, Life Technologies; Vega Thurber et al. 2009) and stored at $-20^{\circ} \mathrm{C}$ until processing. Prior to DNA extraction, excess RNAlater solution was removed (Vega Thurber et al. 2009, Tout et al. 2015) before fragments were air-picked into sterile PBS-EDTA. DNA was extracted from the tissue slurry using the Qiagen DNeasy Plant Mini Kit according to the manufacturer's instructions. To disrupt the Symbiodiniaceae cells, $200 \mu \mathrm{l}$ of $0.5 \mathrm{~mm}$ sterile glass beads (BioSpec) were bead-beaten at $30 \mathrm{~Hz}$ for $90 \mathrm{~s}$ with a Tissue Lyser II (Qiagen). Quantity and quality of DNA was checked using a NanoDrop 2000C spectrophotometer (Thermo Fisher Scientific). PCR amplifications were performed in triplicate reactions with a Qiagen Multiplex PCR Kit.

PCR amplification of the internal transcribed spacer 2 (ITS2) region was done using the primers ITSintfor2 and ITS2-reverse (Illumina sequencing adapters underlined), and following the PCR conditions of Arif et al. (2014):

ITSintfor2: 5'-TCG TCG GCA GCG TCA GAT GTG TAT AAG AGA CAG GAA TTG CAG AAC TCC GTG-3'

ITS2-reverse: 5'-GTC TCG TGG GCT CGG AGA TGT GTA TAA GAG ACA GGG GGA TCC ATA TGC TTA AGT TCA GCG GGT-3'

For individual PCR reactions, DNA was aliquoted to $12-50 \mathrm{ng} \mathrm{l}^{-1}$, with $10 \mu \mathrm{l}$ Qiagen Mix, $0.5 \mu \mathrm{l}$ of each $10 \mathrm{M}$ primer mix, $1 \mu \mathrm{l}$ of DNA template, and DNAsefree water to adjust the reaction volume to $20 \mu \mathrm{l}$. A $5 \mathrm{\mu l}$ aliquot of each PCR product was run on an $1 \%$ agarose gel to visualise successful amplification. Samples were purified and indexed to add Nextera $\mathrm{XT}$ indexing and sequencing adapters (Illumina) according to the manufacturer's protocol. Indexed amplicons were again purified, quantified on the QuBit (Quant-IT dsDNA Broad Range Assay Kit; Invitrogen) and pooled in equimolar ratios on the BioAnalyser (Agilent Technologies). The final pooled library was purified on a $2 \%$ agarose gel to remove 
excess primer-dimers. The library was sequenced at 8 pmol with $10 \%$ phiX on the Illumina Miseq, $2 \times 300 \mathrm{bp}$ end version 3 chemistry according to the manufacturer's specifications, at the Ramaciotti Centre for Genomics.

The SymPortal analytical framework (Hume et al. 2019) was used to predict putative Symbiodiniaceae taxa (LaJeunesse et al. 2018) from the ITS2 marker. The framework uses nextgeneration amplicon sequencing data to identify specific sets of defining intragenomic ITS2 sequence variants (DIVs) that are the taxonomic unit of SymPortal (as the ITS2 type profile) indicative of genetically differentiated Symbiodiniaceae taxa. Demultiplexed and paired forward and reverse fastq.gz files outputted from the Illumina sequencing were submitted directly to SymPortal. Sequence quality control was conducted as part of the SymPortal pipeline using Mothur 1.39.5 (Schloss et al. 2009), the BLAST+ suite of executables (Camacho et al. 2009) and minimum entropy decomposition (Eren et al. 2015).

Differences in coral-associated Symbiodiniaceae between coral species and habitats were analysed using permutational multivariate analysis of variance (PERMANOVA). Fixed factors (species and habitat) were nested according to hierarchy, and 999 permutations of residuals were conducted based on BrayCurtis distances between square-root transformed samples using the PRIMER-E software with the PERMANOVA+ add-on package v.1.0.6 (Clarke \& Gorley 2006).

\section{RESULTS}

\subsection{Environmental characterisation}

The mangrove lagoons of Woody Isles and Howick Island had warmer temperatures and lower oxygen and $\mathrm{pH}$ conditions than the adjacent reef locations during the June 2017 assessment (Tables S1 \& S2, $t$-tests, $\mathrm{p}<0.005)$. As expected, both mangrove lagoons were characterised by large diel variations in temperature, $\mathrm{pH}$ and oxygen (Table 2). The long-term data collection at Woody Isles (February-April 2018; Table 1) revealed that repeatable diel variation influenced by both tide and time of day (Fig. 1). Tempera- ture had greater influence than time of day, particularly during daylight hours $\left(\mathrm{R}^{2}=0.303, \mathrm{n}=6628, \mathrm{p}<\right.$ $0.0001)$, while $\mathrm{pH}_{\mathrm{T}}$ and oxygen were influenced more by tidal height $\left(\mathrm{R}^{2}=0.246\right.$ and 0.210 respectively, $\mathrm{n}=$ 238, p < 0.0001; Fig. S2, Table S3).

Temperatures within the Woody Isles mangrove lagoon during the warmest months exceeded $33^{\circ} \mathrm{C}$, while oxygen fell below $0.6 \mathrm{mg} \mathrm{l}^{-1}$ and $\mathrm{pH}$ regularly dropped below $\mathrm{pH} 7.6$, getting as low as $\mathrm{pH} 7.212$ (Fig. 1). Salinity generally remained between 33 and 36; however, 3 large rainfall events (data obtained from the Australian Bureau of Meteorology) resulted in extreme reductions in salinity, with values decreasing to as low as 18 (Table 2, Fig. S3). Consequently, while the Woody Isles mangrove lagoon does not appear to have an inherent freshwater catchment, influxes of fresh water from the island during large storm events clearly occur. Daily PAR during the warmest months also revealed similar mean light intensities between habitats, with the mangrove lagoon having ca. 5\% greater mean PAR than the reef habitat (Fig. S4).

Spot sampling conducted at the Woody Isles mangrove lagoon to assess the carbonate chemistry parameters (June 2017 and February 2018, Table 1) revealed relatively conserved aragonite saturation state $\left(\Omega_{\text {arg }}\right)$ across seasons (Table S4). The $\mathrm{nA}_{\mathrm{T}}-\mathrm{nC}_{\mathrm{T}}$ slopes were 0.11 and 0.070 for the summer and winter, respectively, with minimal correlation between $\mathrm{nA}_{\mathrm{T}}$ and $\mathrm{nC}_{\mathrm{T}}\left(\mathrm{R}^{2}<0.02 ;\right.$ Fig. 2). Consequently, the 


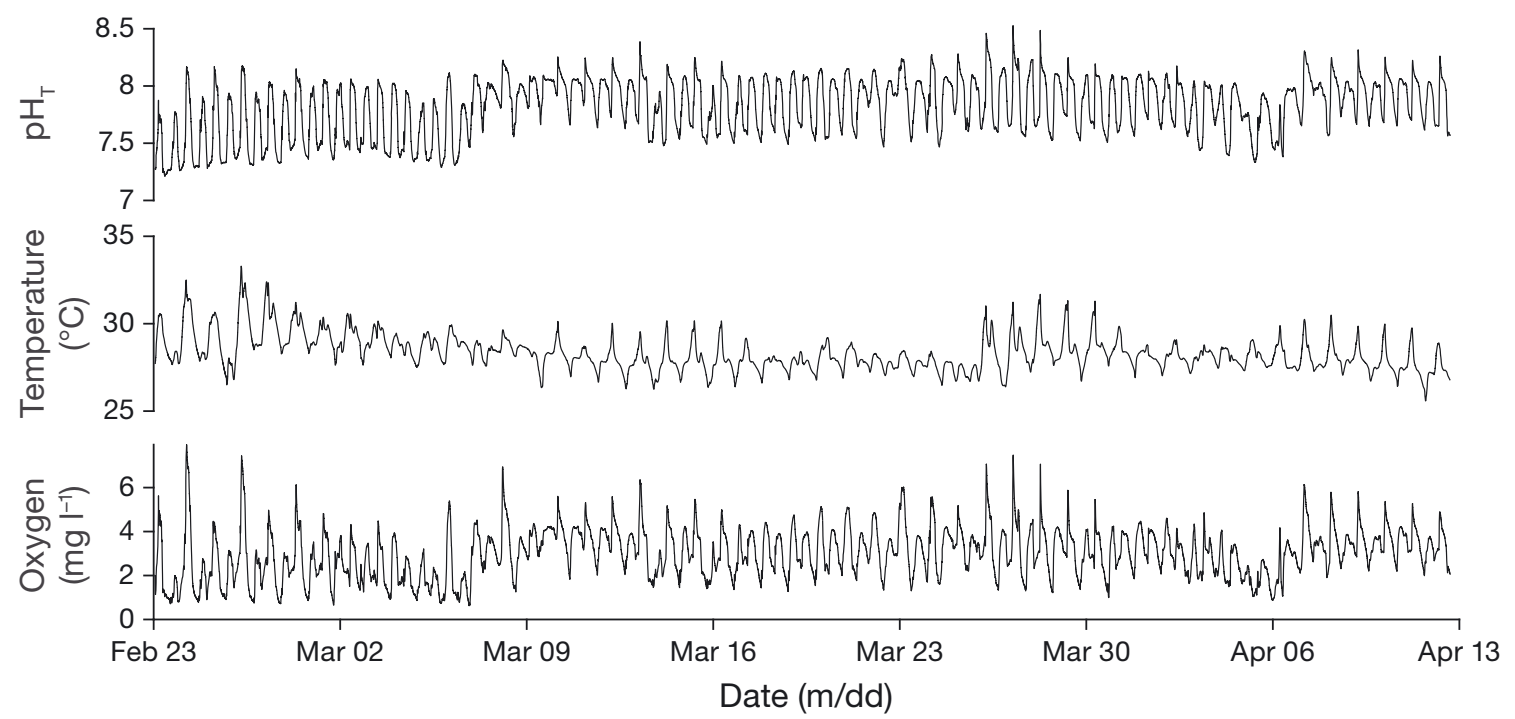

Fig. 1. Abiotic parameters (total $\mathrm{pH}\left[\mathrm{pH}_{\mathrm{T}}\right]$, temperature and dissolved oxygen) of Woody Isles mangrove lagoon on the Great Barrier Reef measured over a 50 d period between February and April 2018. Data were obtained from a SeapHO ${ }^{\mathrm{TM}}$ sensor set to $\log$ every $10 \mathrm{~min}$

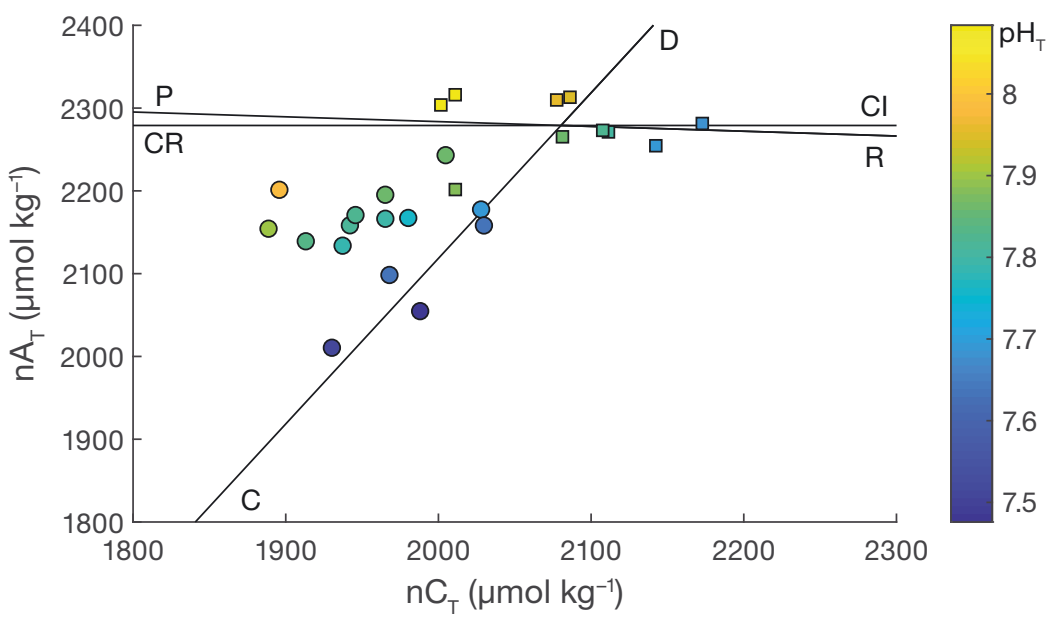

Fig. 2. Salinity-normalised $(\mathrm{S}=36)$ total alkalinity $\left(\mathrm{nA}_{\mathrm{T}}\right)$ and dissolved inorganic carbon $\left(\mathrm{nC}_{\mathrm{T}}\right)$ plots for the Woody Isles mangrove lagoon during June 2017 (squares) and February 2018 (circles). Black lines represent the theoretical impact of calcification (C), carbonate sediment dissolution (D), photosynthesis $(\mathrm{P}), \mathrm{CO}_{2}$ release $(\mathrm{CR}), \mathrm{CO}_{2}$ invasion $(\mathrm{CI})$ and respiration $(\mathrm{R})$ on $\mathrm{nA}_{\mathrm{T}}$ and $\mathrm{nC}_{\mathrm{T}} . \mathrm{C}$ and $\mathrm{D}$ are dominant processes when a linear regression slope approaches 2. Linear regression for each period was as follows: February 2018: $y=0.11 x+1722.3, \mathrm{R}^{2}=0.0217 ;$ June 2017: $y=-0.07 x+2239.5, \mathrm{R}^{2}=0.0018$

\subsection{Benthic characterisation}

Despite the large variability in physicochemical conditions at the Woody Isles and Howick Island mangrove lagoons, both locations housed significant scleractinian coral communities. Coral cover at both mangrove lagoons was low (<5\%, Fig. 3); however, broad visual exploration of the sites revealed that cover was highly heterogeneous, with some areas having much higher coral cover (see Figs. S1 \& S5), while other areas lacked any corals. In total, 29 coral species were identified at the Howick Island mangrove lagoon, while 12 were identified at the Woody Isles mangrove lagoon (Table 3). Both sites housed corals with diverse growth forms (including: caespitose, corymbose, digitate, encrusting, foliose, massive and solitary) that were also taxonomically diverse. Both sites were

carbonate chemistry of the mangrove lagoon is not clearly dominated by calcification-dissolution or photosynthesis-respiration processes, highlighting the complex interplay of biogeochemical processes contributing to the abiotic conditions. However, a longer data series that also encapsulates storm events will ultimately be required to better resolve the dominant influences upon the mangrove lagoon complex carbonate chemistry. dominated by smaller colonies $(<10 \mathrm{~cm}$ diameter), but Howick Island had larger coral colonies exceeding 0.5 m diameter (Fig. 3).

\subsection{Woody Isles coral physiology}

For 2 of the dominant coral species found within the Woody Isles mangroves and neighbouring reefs 


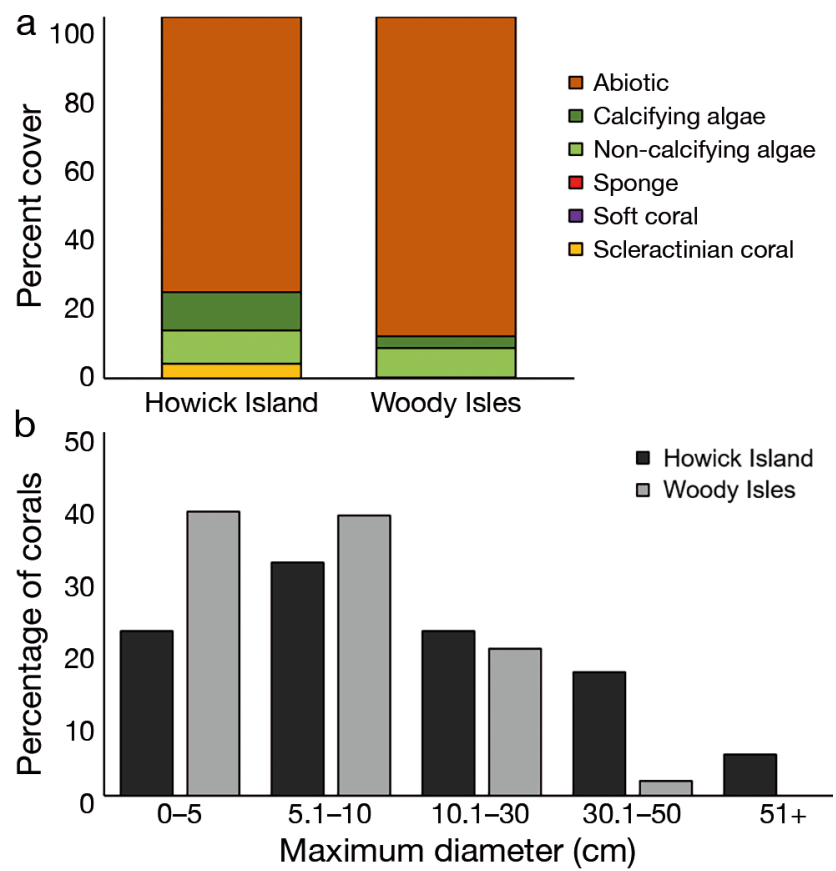

Fig. 3. (a) Percentage cover of major benthic taxa of the Howick Island and Woody Isles mangrove lagoons (see Fig. S5 for reef comparisons). (b) Size-frequency distribution of coral within the Woody Isles and Howick Island mangrove lagoons. Data are averaged from $30 \mathrm{~m}$ transects $(\mathrm{n}=3)$ conducted within each habitat in June 2017

(Acropora millepora and Porites lutea), light calcification was reduced in the mangrove lagoon compared to the reef $\left(F_{1,12}=4.96, \mathrm{p}=0.041\right.$, reduction of $23 \%$ for A. millepora and $30 \%$ for P. lutea; Fig. 4, Table 4). Similarly, dark calcification was also reduced for corals in the mangrove lagoon relative to the reef $\left(F_{1,12}=7.14, \mathrm{p}=0.017\right.$; Fig. 4$)$. For P. lutea from the mangrove lagoon, the reduction in dark calcification was comparable to the reduction in light calcification (ca. $22 \%$ ), whereas for A. millepora, the reduction in dark calcification was 2 times greater than that of light calcification (ca. 47\%; Fig. 4). Respiration was enhanced for both species in the mangrove lagoon $\left(F_{1,16}=\right.$ 8.44, $\mathrm{p}=0.01$ ), and while net photosynthesis was reduced $\left(F_{1,16}=5.78, p=0.029\right.$; Table 4$)$, compared to the reef, gross photosynthesis remained unchanged between habitats $\left(F_{1,16}=0.004, \mathrm{p}=0.951\right.$; Table 4$)$.

Examination of Symbiodiniaceae cell density and genotype revealed distinct patterns for the corals across habitats. Symbiodiniaceae cell density was higher for colonies of both coral species in the mangrove lagoon than at the reef $\left(F_{1,12}=1.5 \times 10^{31}, \mathrm{p}<\right.$ $0.0001)$, which resulted in reduced gross photosynthesis per cell $\left(F_{1,12}=203.7, \mathrm{p}<0.0001\right.$; Table 4 , Fig. S6). P. lutea experienced a mean $( \pm \mathrm{SE})$ reduction in gross photosynthesis per cell from $1.60 \pm 0.09 \mathrm{pmol}$
Table 3. Scleractinian coral species list for Woody Isles and Howick Island mangrove lagoons

\begin{tabular}{|c|c|}
\hline Woody Isles & Howick Island \\
\hline Acropora millepora & Acropora cytherea \\
\hline Acropora sp. & Acropora humilis \\
\hline Acropora cf. nobilis & Acropora intermedia \\
\hline Acropora cf. pulchra & Acropora tenuis \\
\hline Acropora humilis & Acropora cf. valida \\
\hline Astreopora gracilis & Astreopora gracilis \\
\hline Coelastrea aspera & Coelastrea aspera \\
\hline Favites sp. & Cyphastrea sp. \\
\hline Montipora digitata & Goniastrea sp. 1 \\
\hline Pocillopora acuta & Goniastrea sp. 2 \\
\hline Porites cylindrica & Favia sp. 1 \\
\hline \multirow[t]{18}{*}{ Porites lutea } & Favia sp. 2 \\
\hline & Fungia fungites \\
\hline & Lobophyllia corymbosa \\
\hline & Lobophyllia cf. hemprichii \\
\hline & Montipora digitata \\
\hline & Montipora turtlensis \\
\hline & Oulophyllia sp. \\
\hline & Pavona cf. duerdeni \\
\hline & Pavona sp. \\
\hline & Platygyra sinensis \\
\hline & Pocillopora acuta \\
\hline & Pocillopora damicornis \\
\hline & Porites cylindrica \\
\hline & Porites lobata \\
\hline & Porites lutea \\
\hline & Seriatopora sp. \\
\hline & Turbinaria mesenterina \\
\hline & Turbinaria reniformis \\
\hline Total $\mathrm{n}=12$ & Total $\mathrm{n}=29$ \\
\hline
\end{tabular}

$\mathrm{O}_{2}$ cell $^{-1} \mathrm{~h}^{-1}$ on the reef to $0.51 \pm 0.03 \mathrm{pmol} \mathrm{O}_{2}$ cell $^{-1}$ $\mathrm{h}^{-1}$ in the mangrove lagoon, while $A$. millepora experienced a larger reduction from $5.40 \pm 0.40 \mathrm{O}_{2}$ cell $^{-1}$ $\mathrm{h}^{-1}$ on the reef to $0.52 \pm 0.03 \mathrm{O}_{2}$ cell $^{-1} \mathrm{~h}^{-1}$ in the mangrove lagoon (Fig. S6). This reduction of gross photosynthesis per cell across habitats was consistent with 'photosynthetic strategies' of the Symbiodiniaceae communities determined via the RLCs, which demonstrated 2 distinct habitat-specific excitation quenching patterns. Both coral species from the mangroves dissipated an increased proportion of absorbed excitation energy via dynamic nonphotochemical quenching ([1-Q]) rather than photochemical quenching ([1-C]) (Fig. 4a,b).

Genotypic characterisation of the associated Symbiodiniaceae taxa revealed a species and habitat effect (PERMANOVA; pseudo- $F_{1,13}=9.82, \mathrm{p}=0.01$; Table S5). A. millepora associated with different Symbiodiniaceae genotypes between habitats, associating primarily with species of the genus Cladocopium on the reef (ITS2 type profile C3-C50c-C50a$\mathrm{C} 3 \mathrm{~b}$; although lesser abundances of Durusdinium species were detected), and Durusdinium in the 
Fig. 4. Coral physiology of $(\mathrm{a}, \mathrm{c}, \mathrm{e})$ Acropora millepora and $(\mathrm{b}, \mathrm{d}, \mathrm{f})$ Porites lutea in the Woody Isles mangrove lagoon (red) compared to the neighbouring Woody Isles reef site (blue). Data were collected in April 2018 ( $\mathrm{n}=4$ per species per habitat). (a,b) Photochemical quenching (1-C) versus nonphotochemical quenching (1-Q), (c,d) gross photosynthesis $\left(\mathrm{P}_{\mathrm{G}}\right)$ and respiration $(\mathrm{R})$, $(\mathrm{e}, \mathrm{f})$ light $\left(\mathrm{G}_{\mathrm{L}}\right)$ and dark $\left(\mathrm{G}_{\mathrm{D}}\right)$ calcification
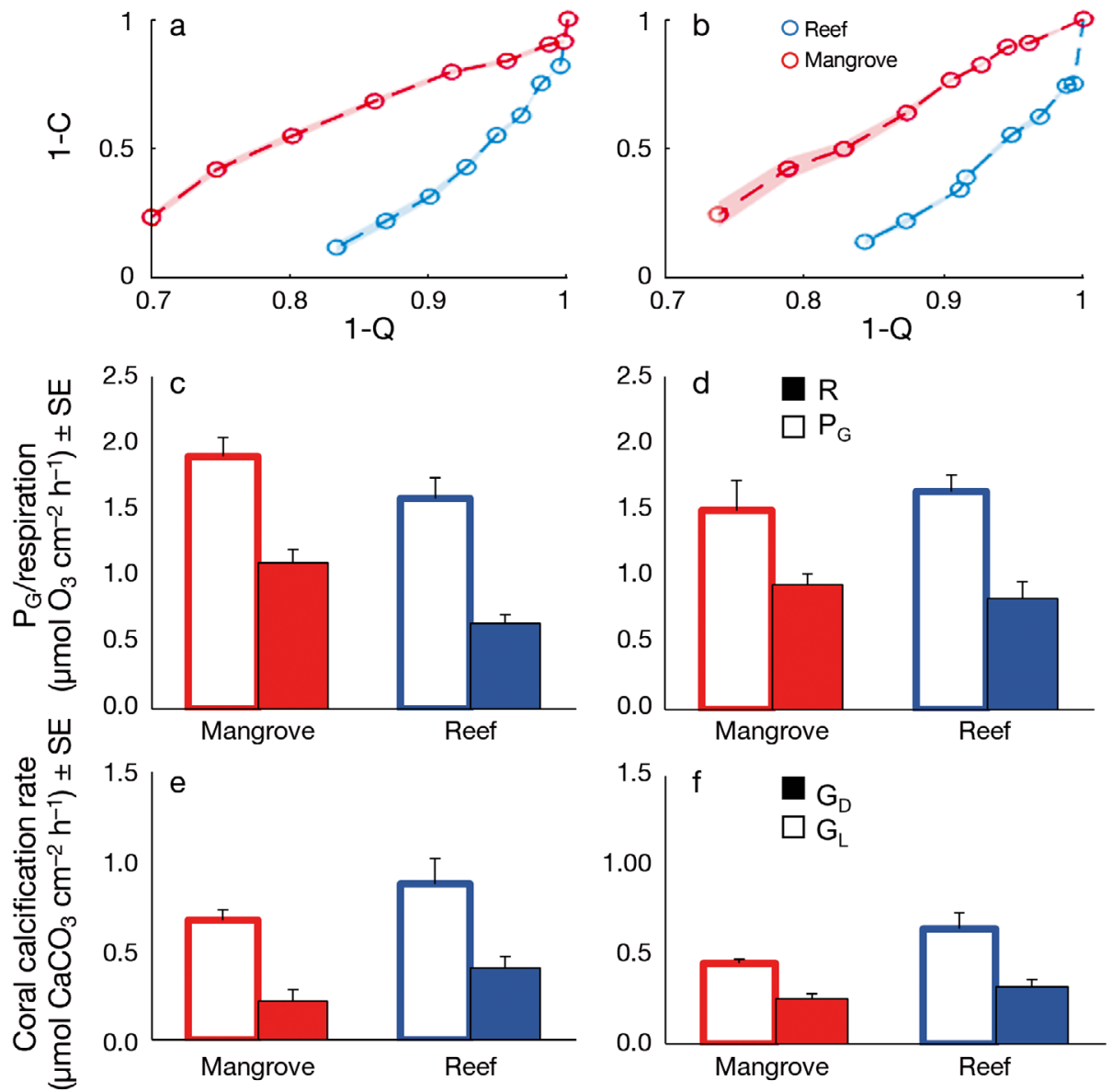

mangrove lagoon (ITS2 type profile D2-D1ak-D1D2.2) (Fig. 5). All P. lutea samples associated with $\mathrm{C} 15$ radiation (Cladocopium) taxa. At the mangrove lagoon, all samples associated with a single genotype (ITS2 type profile C15-C15by-C15bn), but at the reef, 3 distinct ITS2 type profiles (not including the mangrove ITS2 type profile) were identified in the 3 samples (C15, C15-C15bp-C15I-C15n-C15.8 and C15C15I-C15n) (Fig. 5). As such, the changes in both photosynthetic capacity (gross photosynthesis, $\mathrm{P}_{\mathrm{G}}$ ) and strategy (greater non-photochemical dissipation) observed were paralleled by a change in Symbiodiniaceae community composition.

\section{DISCUSSION}

Identification of 2 mangrove lagoons on the Great Barrier Reef, housing diverse coral communities persisting under extreme abiotic conditions, contributes to a growing understanding of hot-spots supporting stress tolerant coral populations. As with previously identified mangrove lagoons housing corals (e.g.
Bouraké, New Caledonia; the Seychelles and Indonesia, see Table S6, Camp et al. 2016a, 2017) the abiotic conditions under which resident corals of Woody Isles and Howick Island are surviving frequently exceed Intergovernmental Panel on Climate Change (IPCC) predictions for seawater conditions in the year 2100 (IPCC 2014). Relative to other previously documented mangrove-coral habitats, the 2 GBR sites expose resident corals to frequently lower $\mathrm{pH}$ (e.g. below 7.3) and oxygen (e.g. below $1.0 \mathrm{mg} \mathrm{l}^{-1}$ ) conditions, making them particularly extreme. The longer-term (50 d) Woody Isles physicochemical dataset revealed the dynamic nature of this specific mangrove lagoon, with a temperature range of ca. $7.7^{\circ} \mathrm{C}$, and $\mathrm{pH}$ range of ca. 1.3 units (Table S6). In addition, the sporadic freshwater input from high rainfall events exposed resident corals to periods of highly variable salinity (range of 16.5 units). Such exposure to large environmental variance appears likely to influence species' responses to climate change (Rivest et al. 2017). For example, frequent exposure to more variable temperature often (Oliver \& Palumbi 2011a, Palumbi et al. 2014, Rivest \& Gouhier 2015, Schoepf 
Table 4. Two-way ANOVA with post hoc Tukey HSD to assess significant interactions between coral species (Acropora millepora and Porites lutea) and habitat (mangrove lagoon and reef) for physiological parameters of corals around Woody Isles. ${ }^{*}$ Indicates significant $\mathrm{p}$-values $(\mathrm{p}<0.05)$; NA: data were not collected during this time point, and thus were not available

\begin{tabular}{|c|c|c|c|c|c|c|}
\hline \multirow{2}{*}{$\begin{array}{l}\text { Physiological } \\
\text { parameter }\end{array}$} & \multirow[t]{2}{*}{ Term } & \multicolumn{3}{|c|}{-ANOVA - } & \multicolumn{2}{|c|}{ Post-hoc Tukey HSD significant interactions } \\
\hline & & $F$ & $\mathrm{df}$ & $\mathrm{p}$ & & \\
\hline \multirow[t]{3}{*}{ Net photosynthesis } & Habitat & 5.784 & 1,16 & $0.029^{*}$ & \multirow{3}{*}{\multicolumn{2}{|c|}{ NA }} \\
\hline & Species & 5.425 & 1,16 & $0.034^{*}$ & & \\
\hline & Habitat:Species & 3.630 & 1,16 & 0.556 & & \\
\hline \multirow[t]{3}{*}{ Gross photosynthesis } & Habitat & 0.004 & 1,16 & 0.951 & \multirow{3}{*}{\multicolumn{2}{|c|}{ NA }} \\
\hline & Species & 1.859 & 1,16 & 0.192 & & \\
\hline & Habitat:Species & 0.797 & 1,16 & 0.385 & & \\
\hline \multirow[t]{3}{*}{ Respiration } & Habitat & 8.444 & 1,16 & $0.010^{*}$ & \multirow{3}{*}{\multicolumn{2}{|c|}{ NA }} \\
\hline & Species & 0.001 & 1,16 & 0.985 & & \\
\hline & Habitat:Species & 3.842 & 1,16 & 0.068 & & \\
\hline \multirow{6}{*}{$\begin{array}{l}\text { Symbiodiniaceae } \\
\text { density }\end{array}$} & Habitat & $1.5 \times 10^{31}$ & 1,12 & $<0.0001^{*}$ & \multirow{6}{*}{\multicolumn{2}{|c|}{$\begin{array}{lr}\text { Reef: } \text { A. mil-Mangroves: } \text { A. mil } & \mathrm{p}<0.0001 \\
\text { Mangroves: P. lut-Mangroves: A. mil } \mathrm{p}<0.0001 \\
\text { Reef: } P \text {. lut-Mangroves: } \text {. mil } & \mathrm{p}<0.0001 \\
\text { Reef: } \text {. mil-Mangroves: } P \text {. lut } & \mathrm{p}<0.0001 \\
\text { Reef: } P \text {. lut-Reef: A. mil } & \mathrm{p}<0.0001 \\
\text { Reef: } \text { P. lut-Mangroves: } P \text {. lut } & \mathrm{p}<0.0001\end{array}$}} \\
\hline & Species & $5.0 \times 10^{25}$ & 1,12 & $<0.0001^{*}$ & & \\
\hline & Habitat:Species & $1.2 \times 10^{30}$ & 1,12 & $<0.0001^{*}$ & & \\
\hline & & & & & & \\
\hline & & & & & & \\
\hline & & & & & & \\
\hline \multirow{5}{*}{$\begin{array}{l}\text { Gross photosynthesis } \\
\text { per cell }\end{array}$} & Habitat & 203.730 & 1,12 & $<0.0001^{*}$ & \multirow{5}{*}{$\begin{array}{l}\text { Reef: } A . \text { mil-Mangroves: } A . \text { mil } \\
\text { Reef: } P \text {. lut-Mangroves: } A . \text { mil } \\
\text { Reef: A. mil-Mangroves: } P . \text { lut } \\
\text { Reef: P. lut-Reef: A. mil } \\
\text { Reef: } P \text {. lut-Mangroves: } P \text {. lut }\end{array}$} & $\mathrm{p}<0.0001$ \\
\hline & Species & 83.910 & 1,12 & $<0.0001^{*}$ & & $\mathrm{p}=0.0112$ \\
\hline & Habitat:Species & 82.970 & 1,12 & $<0.0001^{*}$ & & $\mathrm{p}<0.0001$ \\
\hline & & & & & & $\mathrm{p}<0.0001$ \\
\hline & & & & & & $\mathrm{p}=0.0104$ \\
\hline \multirow[t]{3}{*}{ Light calcification } & Habitat & 4.963 & 1,12 & $0.041^{*}$ & \multirow{3}{*}{\multicolumn{2}{|c|}{ NA }} \\
\hline & Species & 6.393 & 1,12 & $0.022^{*}$ & & \\
\hline & Habitat:Species & 0.005 & 1,12 & 0.9430 & & \\
\hline \multirow[t]{3}{*}{ Dark calcification } & Habitat & 7.139 & 1,12 & $0.017^{*}$ & \multirow{3}{*}{\multicolumn{2}{|c|}{ NA }} \\
\hline & Species & 0.247 & 1,12 & 0.626 & & \\
\hline & Habitat:Species & 1.453 & 1,12 & 0.246 & & \\
\hline
\end{tabular}

et al. 2015), but not always (e.g. Camp et al. 2016b), results in increased tolerance to thermal stress. However, how variance of multiple abiotic parameters influences stress tolerance remains poorly understood and requires further study, most critically since climate change will not only impact seawater temperature, but also other seawater properties, such as $\mathrm{pH}$ and dissolved oxygen (Mora et al. 2013). Despite the extreme physicochemical conditions, coral species found within the 2 GBR mangrove lagoons were taxonomically diverse, with species from the 2 major mitochondrially derived coral clades present (robust and complex; Romano \& Palumbi 1996).

For 2 of the commonly occurring mangrove corals, Acropora millepora and Porites lutea, investigated further within this study, physiological plasticity, along with changes in associated Symbiodiniaceae taxa, appear important in facilitating coral persistence in the mangrove lagoon. Both of these traits ultimately influence energy acquisition, which becomes increasingly important as corals persist towards the edge of their fundamental niche (Sommer et al.
2014). Similar to our previous findings from New Caledonia (Camp et al. 2017), increased respiration rates were evident for coral species in the Woody Isles mangrove lagoon, accompanied by reductions in net photosynthesis and light and dark calcification rates (Fig. 4). It is likely that enhanced heterotrophic nutritional acquisition supports survival of the mangrove corals (see Camp et al. 2017), via provision of additional energy to support physiological maintenance, e.g. greater $\mathrm{pH}$ homeostasis at the site of calcification (Tambutté et al. 2011, 2015). P. lutea has also previously been documented to acclimate to high environmental variance in temperature and $\mathrm{pH}$ through adjustments of heterotrophy versus photosynthetic nutrition (Pacherres et al. 2013).

For both $A$. millepora and P. lutea in the Woody Isles mangrove lagoon, reductions in net photosynthesis were comparable to the reductions in light calcification (Fig. 4). Previous studies have also demonstrated a close coupling of calcification and photosynthesis (Gattuso et al. 1999, Langdon \& Atkinson 2005, Anthony et al. 2008), although their exact relationship 


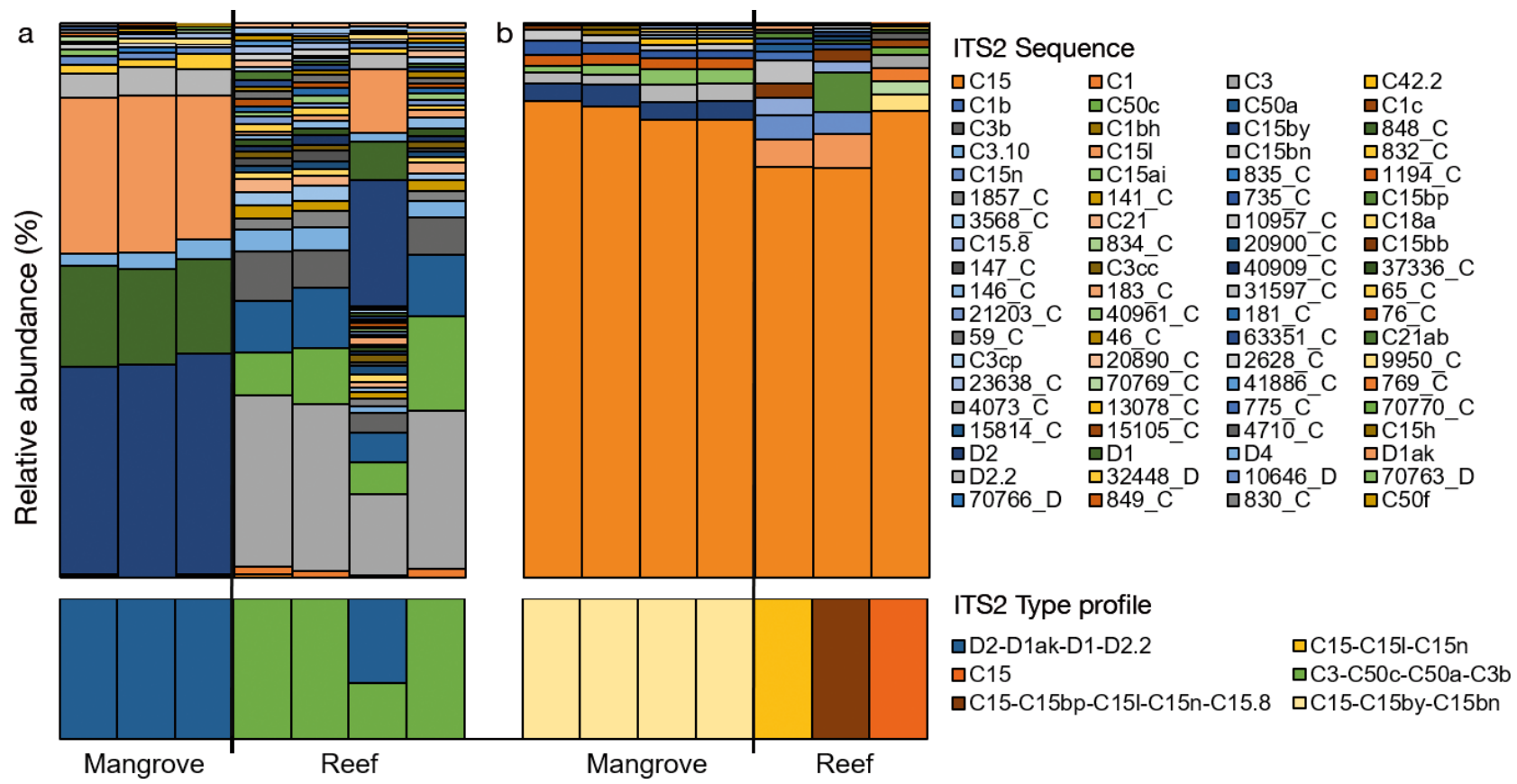

Fig. 5. Recovered ITS2 sequences and predicted ITS2 type profiles for (a) Acropora millepora and (b) Porites lutea across both the mangrove lagoon and reef habitats of Woody Isles on the Great Barrier Reef. Corresponding samples are plotted as stacked bar charts with a single column representing a sample. For each column in the stacked bar plots, the relative abundance of recovered ITS2 sequences is plotted in the upper section, while the relative abundance of predicted ITS2 type profiles is plotted below. Only ITS2 sequences contributing $>0.01 \%$ in at least 1 sample are labelled. Sequences that have been designated names (e.g. C3, C15, or C3bm) refer to sequences that are commonly found in the literature or have been used to characterise ITS2 type profiles as part of this or previous analyses that have been run through the SymPortal analytical framework (Hume et al. 2019). Less common sequences, and those that have not been used to characterise ITS2 type profiles, are named according to a unique database ID and their clade/genera (e.g. 6417_C refers to a sequence with ID 6417 derived from a Cladocopium species, clade C)

remains unresolved at the polyp scale (Allemand et al. 2011, McCulloch et al. 2017). Recent evidence from Porites suggests that changes in Symbiodiniaceae metabolically derived dissolved inorganic carbon is more closely related to the $\mathrm{pH}$ of the corals' calcifying fluid, than the $\mathrm{pH}$ of the surrounding seawater (McCulloch et al. 2017). This suggests that the ability of corals to sustain photosynthesis could be crucial to their ability to calcify in extreme conditions, and consequently coral-associated Symbiodiniaceae are likely an important trait facilitating survival in extreme environments.

Both A. millepora and P. lutea exhibited a change in dominant Symbiodiniaceae taxa when persisting within the mangrove lagoon (Fig. 5). Both coral hosts also only associated with a species-specific single ITS2 type profile in the mangrove lagoon; for $A$. millepora, Durusdinium (ITS2 type profile D2-D1akD1-D2.2), and for P. lutea, Cladocopium (C15-C15byC15bn), indicating specialised algal symbionts (Oliver \& Palumbi 2011b), likely better adapted to the extreme conditions of the mangrove lagoon. Environmental conditions appear fundamental in influencing optimal symbiotic partnerships (Putnam et al. 2012), with changing conditions altering the host's nutritional requirements (Suggett et al. 2017). We hypothesise that the resource landscape changes for corals when they persist into the extreme mangrove lagoons, and thus flexibility in associated Symbiodiniaceae can aid in meeting their metabolic requirements. For both coral species, the change in genotype was also accompanied by an increase in the number of Symbiodiniaceae cells and an overall reduction in gross photosynthesis per cell, with excitation energy dissipation preferentially directed into nonphotochemical quenching (Fig. 4). Symbiodiniaceae have different capacities to preferentially redirect electrons through nonphotochemical pathways - a trait that is known to be important under light stress, but is also likely to be important for exposure to other stressors such as $\mathrm{pH}$ and temperature (Suggett et al. 2015, Nitschke et al. 2018), which occur in the mangrove lagoon. Both coral hosts associated with symbionts in the mangrove lagoon that preferentially selected for nonphotochemical quenching over photochemical quenching (Fig. 4), suggest- 
ing this is an important functional trait for host-symbiotic partners to have within the mangrove lagoon. However, association with a specialised Symbiodiniaceae may come at a cost to the host, such as reduced growth rates, as documented for associations with thermally tolerant Durusdinium symbiont species (Cunning et al. 2015).

Research into extreme inshore coral habitats, such as mangrove lagoons, is still in its infancy (Rivest et al. 2017, Camp et al. 2018b). Only with the increasing decline in global coral cover have researchers begun to consider the broader ecosystem value of such systems that includes preconditioning of corals to extreme conditions (Camp et al. 2016a). The heterogeneous nature of mangrove lagoons results in a variety of potential ecosystem services, including serving as a natural laboratory to study the multitude of complex stressors acting together to challenge the future survival of coral reefs (Camp et al. 2018b); refuge (Yates et al. 2014); climate change preconditioning (Camp et al. 2016a); and housing a potential stock of stress-tolerant corals (Morikawa \& Palumbi 2019). For mangrove lagoons housing stress-tolerant corals, such as Woody Isles and Howick Island, further consideration should be given to the use of their native corals in active interventions, such as assisted gene flow (van Oppen et al. 2015, 2017), translocation of colonies to degraded areas (Anthony et al. 2017) and in coral nurseries (e.g. Suggett et al. 2019). The ability for these corals to tolerate multiple stressors suggests they would provide a valuable source of corals for reef intervention activities.

In consideration of the potential ecosystem services offered by mangrove lagoons, it is important to acknowledge that some sites, such as Woody Isles, only house isolated coral populations, compared to other locations, such as Howick Island, that house an accreting reef framework (Fig. S1). Also, the large reduction in species diversity found within these extreme systems relative to their adjacent reefs likely serves as a warning for future reefs as environmental stress intensifies. Further research is required to establish whether the reduction in species diversity results from a genetic or environmental bottleneck. Environmental filtering was postulated as one potential reason why some coral taxa were absent from a highly variable inshore habitat of the Cayman Islands (Lohr et al. 2017). Presence of both broadcast and spawning coral species suggests that reproductive mode does not explain the presence or absence of coral species from the mangrove lagoon habitats examined here. Individual species traits, water depth, available hard substrate for coral recruitment and lagoon geomorphology appear important in contributing to the resident coral community composition. Further research is also urgently needed to understand if these extreme coral populations are already at the edge of their physiological capacity to cope with multiple stressors, ultimately how much additional stress they can survive under, and whether these extreme coral populations can maintain their stress tolerance when translocated to more environmentally stable reef habitats (Rivest et al. 2017). Despite these unknowns, it appears likely that these mangrove lagoon corals could be among the most capable to persist under future seawater changes over the coming century that will be comprised of a complex interaction of ocean warming, acidification and deoxygenation. To facilitate their survival, enhanced protection of these vital coral reef-mangrove interfaces is required, to limit additional stressors, e.g. nutrient or pollutant input that could damage these disproportionally valuable ecosystems that are still largely unexplored in the context of their role in supporting corals potentially adapted to future climates.

Acknowledgements. We are indebted to Jenny Edmondson and the crew at Wavelength Reef Cruises for their assistance during fieldwork, and we thank Benjamin Hume from KAUST University for assistance with the Symbiodiniaceae bioinformatics. Fieldwork was supported by the Waitt-Foundation-National Geographic Grant awarded to E.F.C., D.J.S., J.R. and A.H. (grant no. 4741-6) and through Australian Research Council Discovery Projects (DP160100271 and DP180100074 to D.J.S.). The contribution of E.F.C. to manuscript writing and final preparation was through the University of Technology Sydney Chancellor's Postdoctoral Research Fellowship.

\section{LITERATURE CITED}

Allemand D, Tambutte E, Zoccola D, Tambutte S (2011) Coral calcification, cells to reefs. In: Dubinsky Z, Stambler $\mathrm{N}$ (eds) Coral reefs: an ecosystem in transition. Springer, London, p 119-150

Anthony KR, Kline DI, Diaz-Pulido G, Dove S, Hoegh-Guldberg $O$ (2008) Ocean acidification causes bleaching and productivity loss in coral reef builders. Proc Natl Acad Sci USA 105:17442-17446

Anthony K, Bay LK, Costanza R, Firn J and others (2017) New interventions are needed to save coral reefs. Nat Ecol Evol 1:1420-1422

Arif C, Daniels C, Bayer T, Banguera-Hinestroza E and others (2014) Assessing Symbiodinium diversity in scleractinian corals via next-generation sequencing-based genotyping of the ITS2 rDNA region. Mol Ecol 23:4418-4433

Camacho C, Coulouris G, Avagyan V, Ma N, Papadopoulos J, Bealer K, Madden TL (2009) BLAST+: architecture and applications. BMC Bioinformatics 10:421 
Camp EF, Suggett DJ, Gendron G, Jompa J, Manfrino C, Smith DJ (2016a) Mangrove and seagrass beds provide different biogeochemical services for corals threatened by climate change. Front Mar Sci 3:52

Camp EF, Smith DJ, Evenhuis C, Enochs I, Manzello D, Woodcock S, Suggett DJ (2016b) Acclimatization to highvariance habitats does not enhance physiological tolerance of two key Caribbean corals to future temperature and pH. Proc R Soc B 283:20160442

* Camp EF, Nitschke MR, Rodolfo-Metalpa R, Houlbreque F and others (2017) Reef-building corals thrive within hotacidified and deoxygenated waters. Sci Rep 7:2434

* Camp EF, Schoepf V, Suggett DJ (2018a) How can 'Super Corals' facilitate global coral reef survival under rapid environmental and climatic change? Glob Change Biol 24:2755-2757

Camp EF, Schoepf V, Mumby PJ, Hardtke LA, Rodolfo-Metalpa R, Smith DJ, Suggett DJ (2018b) The future of coral reefs subject to rapid climate change: lessons from natural extreme environments. Front Mar Sci 5:4

Chollett I, Mumby PJ, Cortés J (2010) Upwelling areas do not guarantee refuge for coral reefs in a warming ocean. Mar Ecol Prog Ser 416:47-56

Clarke KR, Gorley RN (2006) PRIMER v6. User manual/ tutorial. PRIMER-E, Plymouth

Cunning R, Gillette P, Capo T, Galvez K, Baker AC (2015) Growth tradeoffs associated with thermotolerant symbionts in the coral Pocillopora damicornis are lost in warmer oceans. Coral Reefs 34:155-160

De'ath G, Fabricius KE, Sweatman H, Puotinen M (2012) The 27-year decline of coral cover on the Great Barrier Reef and its causes. Proc Natl Acad Sci USA 109: 17995-17999

Dickson AG (1990) Standard potential of the reaction: $\mathrm{AgCl}(\mathrm{s})+1 / 2 \mathrm{H}_{2}(\mathrm{~g})=\mathrm{Ag}(\mathrm{s})+\mathrm{HCl}(\mathrm{aq})$, and the standard acidity constant of the ion $\mathrm{HSO}_{4}{ }^{-}$in synthetic seawater from 273.15 to $318.15 \mathrm{~K}$. J Chem Thermodyn 22:113-127

Enochs IC, Manzello DP, Donham EM, Kolodziej G and others (2015) Shift from coral to macroalgae dominance on a volcanically acidified reef. Nat Clim Chang 5:1083-1088

Eren AM, Morrison HG, Lescault PJ, Reveillaud J, Vineis JH, Sogin ML (2015) Minimum entropy decomposition: unsupervised oligotyping for sensitive partitioning of high-throughput marker gene sequences. ISME J 9: 968-979

Fabricius KE, Langdon C, Uthicke S, Humphrey C and others (2011) Losers and winners in coral reefs acclimatized to elevated carbon dioxide concentrations. Nat Clim Chang 1:165-169

F Frade PR, Bongaerts P, Englebert N, Rogers A, GonzalezRivero M, Hoegh-Guldberg O (2018) Deep reefs of the Great Barrier Reef offer limited thermal refuge during mass coral bleaching. Nat Commun 9:3447

Gardner SG, Camp EF, Smith DJ, Kahlke T and others (2019) Coral microbiome diversity reflects mass coral bleaching susceptibility during the 2016 El Niño heat wave. Ecol Evol 9:938-956

Gattuso JP, Allemand D, Frankignoulle M (1999) Photosynthesis and calcification at cellular, organismal and community levels in coral reefs: a review on interactions and control by carbonate chemistry. Am Zool 39:160-183

Hoogenboom MO, Frank GE, Chase TJ, Jurriaans S and others (2017) Environmental drivers of variation in bleaching severity of Acropora species during an extreme thermal anomaly. Front Mar Sci 11:2251-2265
Hughes TP, Barnes ML, Bellwood DR, Cinner JE and others (2017) Coral reefs in the Anthropocene. Nature 546: 82-90

*Hughes TP, Kerry JT, Baird AH, Connolly SR and others (2018) Global warming transforms coral reef assemblages. Nature 556:492-496

Hughes TP, Kerry JT, Baird AH, Connolly SR and others (2019) Global warming impairs stock-recruitment dynamics of corals. Nature 568:387-390

Hume BCC, Smith EG, Ziegler M, Warrington HJM and others (2019) SymPortal: a novel analytical framework and platform for coral algal symbiont next-generation sequencing ITS2 profiling. Mol Ecol Resour 19:1063-1080

IPCC (2014) Climate change 2014: synthesis report. Contribution of Working Groups I, II and III to the Fifth Assessment Report of the Intergovernmental Panel on Climate Change. IPCC, Geneva

Keppel G, Wardell-Johnson GW (2012) Refugia: keys to climate change management. Glob Change Biol 18: 2389-2391

Kleypas JA, Anthony KRN, Gattuso JP (2011) Coral reefs modify their seawater carbon chemistry-case study from a barrier reef (Moorea, French Polynesia). Glob Change Biol 17:3667-3678

* LaJeunesse TC, Parkinson JE, Gabrielson PW, Jeong HJ, Reimer JD, Voolstra CR, Santos SR (2018) Systematic revision of Symbiodiniaceae highlights the antiquity and diversity of coral endosymbionts. Curr Biol 28:2570-2580

* Langdon C, Atkinson MJ (2005) Effect of elevated $\mathrm{pCO}_{2}$ on photosynthesis and calcification of corals and interactions with seasonal change in temperature/irradiance and nutrient enrichment. J Geophys Res 110:C09S07

KLohr KE, Smith DJ, Suggett DJ, Nitschke MR, Dumbrell AJ, Woodcock F, Camp EF (2017) Coral community structure and recruitment in seagrass meadows. Front Mar Sci 4: 388

* Long MH, Rheuban JE, Berg P, Zieman JC (2012) A comparison and correction of light intensity loggers to photosynthetically active radiation sensors. Limnol Oceanogr Methods 10:416-424

* Lueker TJ, Dickson AG, Keeling CD (2000) Ocean $p \mathrm{CO}_{2}$ calculated from dissolved inorganic carbon, alkalinity, and equations for $\mathrm{K} 1$ and $\mathrm{K} 2$ : validation based on laboratory measurements of $\mathrm{CO}_{2}$ in gas and seawater at equilibrium. Mar Chem 70:105-119

* McCulloch MT, D'Olivo JP, Falter J, Holcomb M, Trotter JA (2017) Coral calcification in a changing world and the interactive dynamics of $\mathrm{pH}$ and DIC upregulation. Nat Commun 8:15686

*McMahon A, Santos IR, Schulz KG, Scott A, Silverman J, Davis KL, Maher DT (2019) Coral reef calcification and production after the 2016 bleaching event at Lizard Island, Great Barrier Reef. J Geophys Res Oceans 124: 4003-4016

* Mora C, Wei CL, Rollo A, Amaro T and others (2013) Biotic and human vulnerability to projected changes in ocean biogeochemistry over the 21st century. PLOS Biol 11: e1001682

* Morgan KM, Perry CT, Johnson JA, Smithers SG (2017) Nearshore turbid-zone corals exhibit high bleaching tolerance on the Great Barrier Reef following the 2016 ocean warming event. Front Mar Sci 4:224

Morikawa MK, Palumbi SR (2019) Using naturally occurring climate resilient corals to construct bleaching-resistant nurseries. Proc Natl Acad Sci USA 116:10586-10591 
Nitschke MR, Gardner SG, Goyen S, Fujise L, Camp EF, Ralph PJ, Suggett DJ (2018) Utility of photochemical traits as diagnostics of thermal tolerance amongst Great Barrier Reef corals. Front Mar Sci 5:45

Oliver TA, Palumbi SR (2009) Distributions of stress-resistant coral symbionts match environmental patterns at local but not regional scales. Mar Ecol Prog Ser 378: 93-103

Oliver TA, Palumbi SR (2011a) Do fluctuating temperature environments elevate coral thermal tolerance? Coral Reefs 30:429-440

Oliver TA, Palumbi SR (2011b) Many corals host thermally resistant symbionts in high-temperature habitat. Coral Reefs 30:241-250

Oliver ECJ, Donat MG, Burrows MT, Moore PJ and others (2018) Longer and more frequent marine heatwaves over the past century. Nat Commun 9:1324

* Osman EO, Smith DJ, Ziegler M, Kürten B and others (2018) Thermal refugia against coral bleaching throughout the northern Red Sea. Glob Change Biol 24:e474-e484

Pacherres CO, Schmidt GM, Richter C (2013) Autotrophic and heterotrophic responses of the coral Porites lutea to large amplitude internal waves. J Exp Biol 216:4365-4374

Palumbi SR, Barshis DJ, Traylor-Knowles N, Bay RA (2014) Mechanisms of reef coral resistance to future climate change. Science 344:895-898

Putnam HM, Stat M, Pochon X, Gates RD (2012) Endosymbiotic flexibility associates with environmental sensitivity in scleractinian corals. Proc R Soc B 29:20121454

Rivest EB, Gouhier TC (2015) Complex environmental forcing across the biogeographical range of coral populations. PLOS ONE 10:e0121742

Rivest EB, Comeau S, Cornwall CE (2017) The role of natural variability in shaping the response of coral reef organisms to climate change. Curr Clim Change Rep 3: 271-281

Romano SL, Palumbi SR (1996) Evolution of scleractinian corals inferred from molecular systematics. Science 271: 640-642

RStudio Team (2015) RStudio: integrated development for R. RStudio, Boston, MA. www.rstudio.com

Schloss PD, Westcott SL, Ryabin T, Hall JR and others (2009) Introducing mothur: open-source, platform-independent, community-supported software for describing and comparing microbial communities. Appl Environ Microbiol 75:7537-7541

Schoepf V, Stat M, Falter JL, McCulloch MT (2015) Limits to the thermal tolerance of corals adapted to a highly fluctuating, naturally extreme temperature environment. Sci Rep 5:17639

Smith SV, Kinsey DW (1978) Calcification and organic carbon metabolism as indicated by carbon dioxide. In: Stoddart DR, Johannes RE (eds) Coral reefs: research methods. Monogr Oceanogr Methodol 5:469-484

Smith LW, Barshis D, Birkeland C (2007) Phenotypic plasticity for skeletal growth, density and calcification of Porites lobata in response to habitat type. Coral Reefs 26 : 559-567

Sommer B, Harrison PL, Beger M, Pandolfi JM (2014) Traitmediated environmental filtering drives assembly at biogeographic transition zones. Ecology 95:1000-1009
Strahl J, Stolz I, Uthicke S, Vogel N, Noonan SH, Fabricius KE (2015) Physiological and ecological performance differs in four coral taxa at a volcanic carbon dioxide seep. Comp Biochem Physiol Part A Mol Integr Physiol 184: 179-186

Suggett DJ, Kikuchi RK, Oliveira MD, Spanó S, Carvalho R, Smith DJ (2012) Photobiology of corals from Brazil's near-shore marginal reefs of Abrolhos. Mar Biol 159: 1461-1473

Suggett DJ, Goyen S, Evenhuis C, Szabó M, Pettay DT, Warner ME, Ralph PJ (2015) Functional diversity of photobiological traits within the genus Symbiodinium appears to be governed by the interaction of cell size with cladal designation. New Phytol 208:370-381

Suggett DJ, Warner ME, Leggat W (2017) Symbiotic dinoflagellate functional diversity mediates coral survival under ecological crisis. Trends Ecol Evol 32:735-745

Suggett DJ, Camp EF, Edmondson J, Boström-Einarsson L, Ramler V, Lohr K, Patterson JT (2019) Optimizing returnon-effort for coral nursery and outplanting practices to aid restoration of the Great Barrier Reef. Restor Ecol 27: 683-693

Suzuki S, Kawahata H (2003) Carbon budget of coral reef systems: an overview of observations in fringing reefs, barrier reefs and atolls in the Indo-Pacific regions. Tellus 55:428-444

* Sweatman H, Delean S, Syms C (2011) Assessing loss of coral cover on Australia's Great Barrier Reef over two decades, with implications for longer-term trends. Coral Reefs 30:521-531

* Tambutté S, Holcomb M, Ferrier-Pagès C, Reynaud S, Tambutté E, Zoccola D, Allemand D (2011) Coral biomineralization: from the gene to the environment. J Exp Mar Biol Ecol 408:58-78

* Tambutté E, Venn AA, Holcomb M, Segonds N and others (2015) Morphological plasticity of the coral skeleton under $\mathrm{CO}_{2}$-driven seawater acidification. Nat Commun 6:7368

Tout J, Siboni N, Messer LF, Garren M and others (2015) Increased seawater temperature increases the abundance and alters the structure of natural Vibrio populations associated with the coral Pocillopora damicornis. Front Microbiol 6:432

Uppström LR (1974) The boron/chlorinity ratio of deep-sea water from the Pacific Ocean. Deep-Sea Res 21:161-162

*Van Hooidonk R, Maynard JA, Planes S (2013) Temporary refugia for coral reefs in a warming world. Nat Clim Chang 3:508-511

Van Oppen MJ, Oliver JK, Putnam HM, Gates RD (2015) Building coral reef resilience through assisted evolution. Proc Natl Acad Sci USA 112:2307-2313

Van Oppen MJ, Gates RD, Blackall LL, Cantin N and others (2017) Shifting paradigms in restoration of the world's coral reefs. Glob Change Biol 23:3437-3448

*Vega Thurber R, Willner-Hall D, Rodriguez-Mueller B, Desnues C and others (2009) Metagenomic analysis of stressed coral holobionts. Environ Microbiol 11:2148-2163

* Yates KK, Rogers CS, Herlan JJ, Brooks GR, Smiley NA, Larson RA (2014) Diverse coral communities in mangrove habitats suggest a novel refuge from climate change. Biogeosciences 11:4321-4337

Submitted: May 14, 2019; Accepted: July 12, 2019

Proofs received from author(s): August 24, 2019 